\title{
Comparative Study of Lavh Vs. Abdominal Hysterectomy Done By A Beginner for Laparoscopic Surgeries In A Govt Medical College Hospital
}

\author{
Dr.N.Geetha ${ }^{1}$, Dr.Manimegalai ${ }^{2}$ \\ ( ${ }^{I}$ Dr.N.Geetha, Associate professor, Department of OBG, GMKMCH, Dr.MGR University, India) \\ $\left({ }^{2}\right.$ Dr.Manimegalai, Assistant professor, Department of OBG, GMKMCH, Dr.MGR University, India $)$
}

\begin{abstract}
:
Aim: It is a retrospective study to compare the LAVH done by a beginner for laparoscopic surgeries and abdominal hysterectomy cases done by the same team of surgeons.

Introduction: Laparoscopic surgeries are replacing open surgeries in all fields.Most of the gynaecologists, who are well trained in open surgeries, are hesitant to start doing laparoscopic surgeries.This study which compares LAVH done by a beginner with abdominal hysterectomy will be beneficial for them.

Methodology: This study was done in GMKMCH, Salem from March 2015-March 2016. We have done about 40 cases of LAVH and compared with 40 cases of abdominal hysterectomy done by same team of surgeons.

Results: During the initial period when LAVH cases were started the complication rate and conversion to laparotomy cases were high. The duration of surgery was long about (2 hr. 30 minutes- $3 \mathrm{hrs}$.) in the initial period which was reduced to less than $1 \mathrm{hr}$. 30 minutes after 6 months.

Conclusion: The Gynaecologists in govt. tertiary health centres can start doing LAVH cases instead of laparotomies for gynaecological surgeries and this will be a gateway for doing other laparoscopic surgeries (laparoscopic myomeclaprascopic,tomy, TLH ,Lap ovarian cystectomy, Lap.Wertheimsetc).
\end{abstract}

Keywords: laparoscopic, hysterectomy,

\section{Introduction}

All gynaecologists are well versed in doing abdominal hysterectomies. Nowadays in Medical College Hospital \&taluk hospital operative laparoscope instruments are available and all types of Laparoscope surgeries are being done in various departments. In our department we have started doing LAVH cases from 2015 and we have done about 40 cases .we will discuss the merits and demerits of LAVH surgeries and will compare with same number of and hysterectomy cases done by same team of surgeons.

\section{Methods:}

It is a retrospective study done in GMKMCH of cases which have been posted for LAVH and abdominal hysterectomy to know about difficulties of the surgeon, duration of surgery complications (intra OP $\&$ Post OP) duration of hospital stay and postoperative pain.

\section{Selection criteria:}

Benign conditions such as DUB, Adenomyosis

Fibroid uterus less than 12 weeks

Previous normal deliveries

Multiparous

\section{Exclusion criteria:}

Cases with previous laparotomies

Previous uterine surgeries

Uterine size more than 12 weeks

Cases with associated ovarian pathology

Nulligravida

\section{Results:}

Out of 40 cases of LAVH the average of blood loss was $97 \mathrm{ml}$ and in abdominal hysterectomy cases the average blood loss was $261 \mathrm{ml}$ (P Value<.001) which is significant. The duration of surgery for LAVH was initially long (average 152minutes) in the first 20 cases which later became reduced to less than 120 minutes. The average length of hospital stay for LAVH was 3.5 days compared to abdominal hysterectomy cases which 
was 7 days (Pvalue <0.001). In LAVH cases in the initial 6 months the conversion to Laparotomy was higher which became reduced in the last 6 months. Post-operative pain was very much less in LAVH cases compared to abdominal hysterectomy.

\begin{tabular}{|c|c|c|c|c|c|c|}
\hline & Group & $\mathbf{N}$ & Mean & SD & $\mathbf{t}$ & $\mathbf{p}$ \\
\hline \multirow{2}{*}{ Age } & LAVH & 33 & 42.52 & 5.52 & \multirow{2}{*}{2.24} & \multirow{2}{*}{$0.028 *$} \\
\hline & Abdominal & 40 & 46.10 & 7.68 & & \\
\hline \multirow{2}{*}{$\begin{array}{c}\text { Duration of } \\
\text { Surgery (minutes) }\end{array}$} & LAVH & 33 & 123.64 & 22.61 & \multirow{2}{*}{14.97} & \multirow{2}{*}{$<0.001 * *$} \\
\hline & Abdominal & 40 & 61.38 & 12.25 & & \\
\hline \multirow{2}{*}{ Blood Loss (ML) } & LAVH & 33 & 105.15 & 56.67 & \multirow{2}{*}{6.86} & \multirow{2}{*}{$<0.001 * *$} \\
\hline & Abdominal & 40 & 268.75 & 126.94 & & \\
\hline \multirow{2}{*}{$\begin{array}{l}\text { Length of Hospital } \\
\text { stay (days) }\end{array}$} & LAVH & 33 & 3.52 & 0.57 & \multirow{2}{*}{8.65} & \multirow{2}{*}{$<0.001 * *$} \\
\hline & Abdominal & 40 & 7.03 & 2.27 & & \\
\hline
\end{tabular}

** Highly significant (Significant at $1 \%$ ); *Significant at $5 \%$
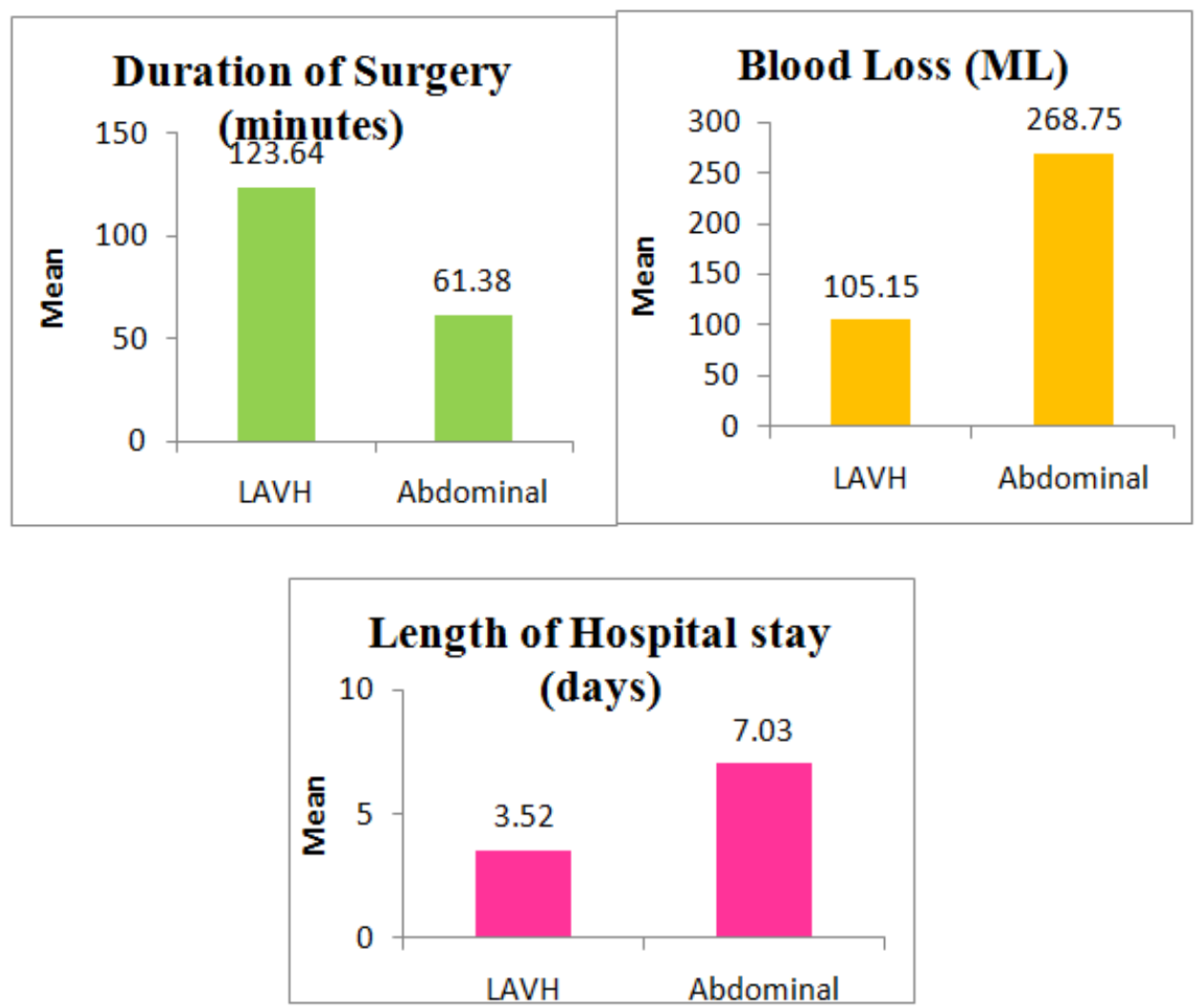

\begin{tabular}{|c|c|c|c|c|c|c|c|c|c|}
\hline \multirow{3}{*}{ Group } & \multicolumn{6}{|c|}{ Post op pain } & \multirow{3}{*}{ Total } & \multirow{3}{*}{$\begin{array}{c}\text { Chi } \\
\text { square }\end{array}$} & \multirow{3}{*}{$\mathbf{p}$} \\
\hline & \multicolumn{2}{|c|}{ Mild } & \multicolumn{2}{|c|}{$\begin{array}{l}\text { Moder } \\
\text { ate }\end{array}$} & \multicolumn{2}{|c|}{ Severe } & & & \\
\hline & $\mathbf{N}$ & $\%$ & $\mathbf{N}$ & $\%$ & $\mathrm{~N}$ & $\%$ & & & \\
\hline LAVH & 19 & 58 & 14 & 42 & & & 33 & & $<$ \\
\hline $\begin{array}{c}\text { Abdomi } \\
\text { nal }\end{array}$ & & & 21 & 53 & $\begin{array}{l}1 \\
9\end{array}$ & 48 & 40 & נת.0 & \\
\hline Total & 19 & 26 & 35 & 48 & $\begin{array}{l}1 \\
9\end{array}$ & 26 & 73 & & \\
\hline
\end{tabular}

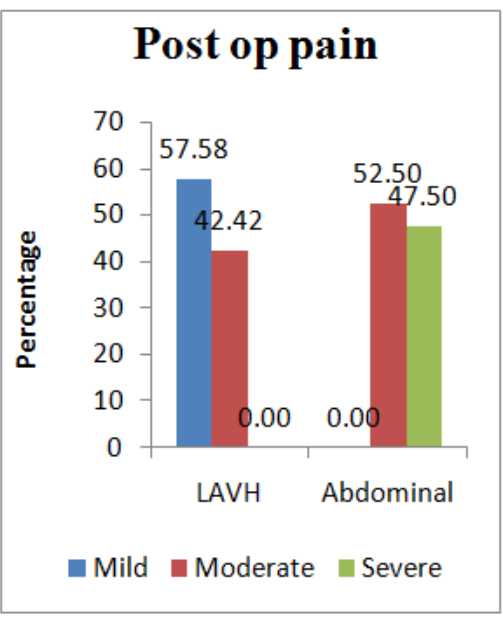

**Highly significant (Significant at $1 \%$ ) 


\begin{tabular}{|c|c|c|c|c|c|c|c|}
\hline \multirow{3}{*}{$\begin{array}{c}\text { Gro } \\
\text { up }\end{array}$} & \multicolumn{4}{|c|}{$\begin{array}{l}\text { Post op wound } \\
\text { infection }\end{array}$} & \multirow{3}{*}{$\begin{array}{l}\text { To } \\
\text { tal }\end{array}$} & \multirow{3}{*}{$\begin{array}{l}\text { Chi } \\
\text { squa } \\
\text { re }\end{array}$} & \multirow{3}{*}{ p } \\
\hline & \multicolumn{2}{|c|}{ Yes } & \multicolumn{2}{|c|}{ No } & & & \\
\hline & $\mathrm{N}$ & $\%$ & $\mathbf{N}$ & $\%$ & & & \\
\hline $\begin{array}{c}\text { LAV } \\
\text { H }\end{array}$ & & & 33 & 100 & 33 & & $\begin{array}{l}0 . \\
0\end{array}$ \\
\hline $\begin{array}{c}\text { Abd } \\
\text { omin } \\
\text { al }\end{array}$ & 5 & 13 & 35 & 88 & 40 & 4.43 & $\begin{array}{l}3 \\
5 \\
*\end{array}$ \\
\hline Total & 5 & 7 & 68 & 93 & 73 & & \\
\hline
\end{tabular}

\section{Post op wound infection}

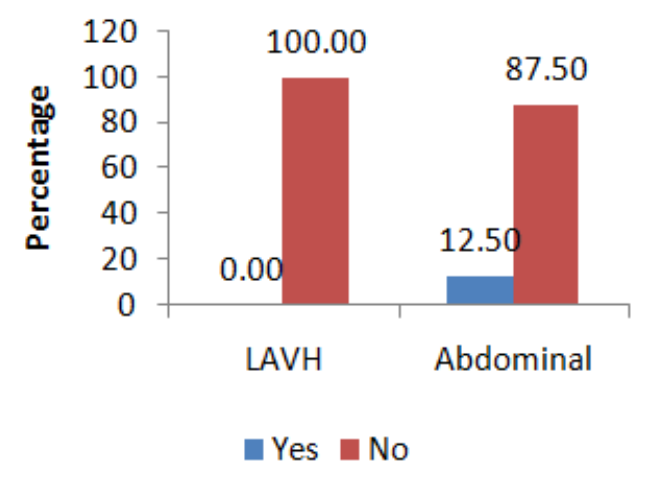

\begin{tabular}{|c|c|c|c|c|c|c|c|}
\hline \multirow{3}{*}{ Group } & \multicolumn{4}{|c|}{$\begin{array}{c}\text { Blood } \\
\text { Transfusion }\end{array}$} & \multirow{3}{*}{ Total } & \multirow{3}{*}{$\begin{array}{c}\text { Chi } \\
\text { squa } \\
\text { re }\end{array}$} & \multirow{3}{*}{ p } \\
\hline & \multicolumn{2}{|c|}{ Yes } & \multicolumn{2}{|c|}{ No } & & & \\
\hline & $\mathbf{N}$ & $\%$ & $\mathbf{N}$ & $\%$ & & & \\
\hline LAVH & 1 & 3 & 32 & 97 & 33 & & \\
\hline Abdominal & 13 & 33 & 27 & 68 & 40 & & \\
\hline Total & 14 & 19 & 59 & 81 & 73 & & \\
\hline
\end{tabular}

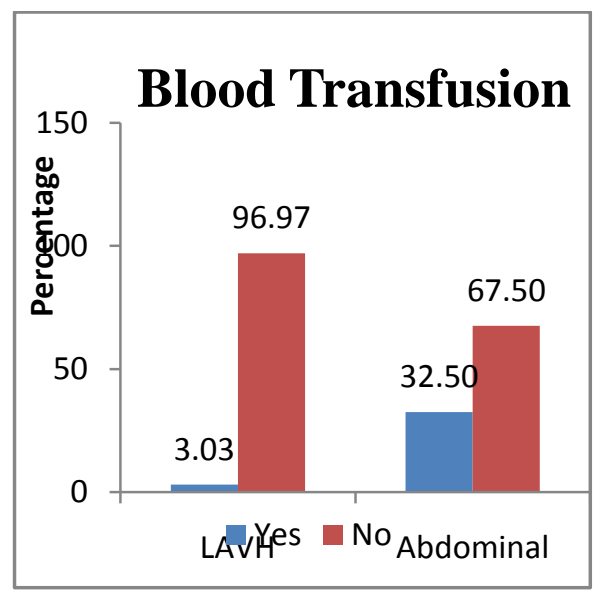

** Highly significant (Significant at $1 \%$ )

\begin{tabular}{|c|c|c|c|c|c|c|}
\hline & Group & $\mathbf{N}$ & Mean & SD & $\mathbf{t}$ & $\mathbf{p}$ \\
\hline \multirow{2}{*}{$\begin{array}{l}\text { Duration } \\
\text { of Surgery } \\
\text { (minutes) }\end{array}$} & LAVH 1 & 16 & 131.56 & 19.38 & \multirow[b]{2}{*}{2.049} & \multirow[b]{2}{*}{$0.049 *$} \\
\hline & LAVH 2 & 17 & 116.18 & 23.42 & & \\
\hline \multirow{2}{*}{$\begin{array}{c}\text { Blood Loss } \\
\text { (ML) }\end{array}$} & LAVH 1 & 16 & 125.00 & 71.65 & \multirow{2}{*}{2.047} & \multirow{2}{*}{$0.049 *$} \\
\hline & LAVH 2 & 17 & 86.47 & 29.09 & & \\
\hline \multirow{2}{*}{$\begin{array}{c}\text { Length of } \\
\text { Hospital } \\
\text { stay (days) }\end{array}$} & LAVH 1 & 16 & 3.75 & 0.58 & \multirow{2}{*}{2.495} & \multirow{2}{*}{$0.018 *$} \\
\hline & LAVH 2 & 17 & 3.29 & 0.47 & & \\
\hline
\end{tabular}

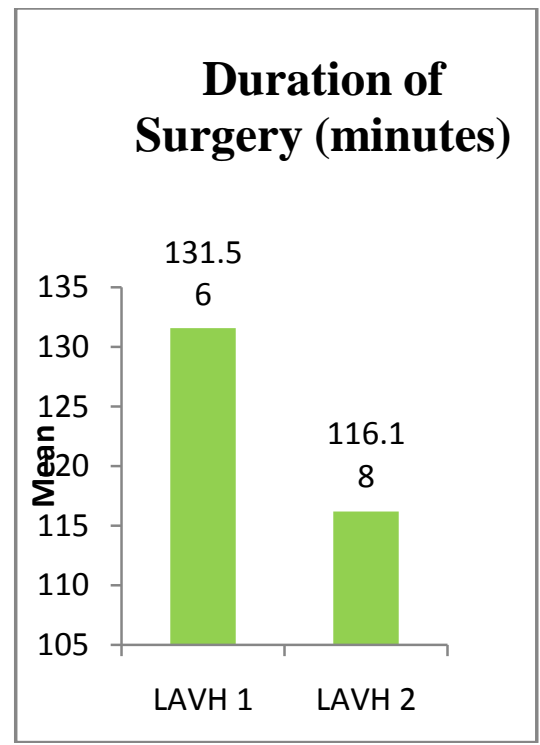




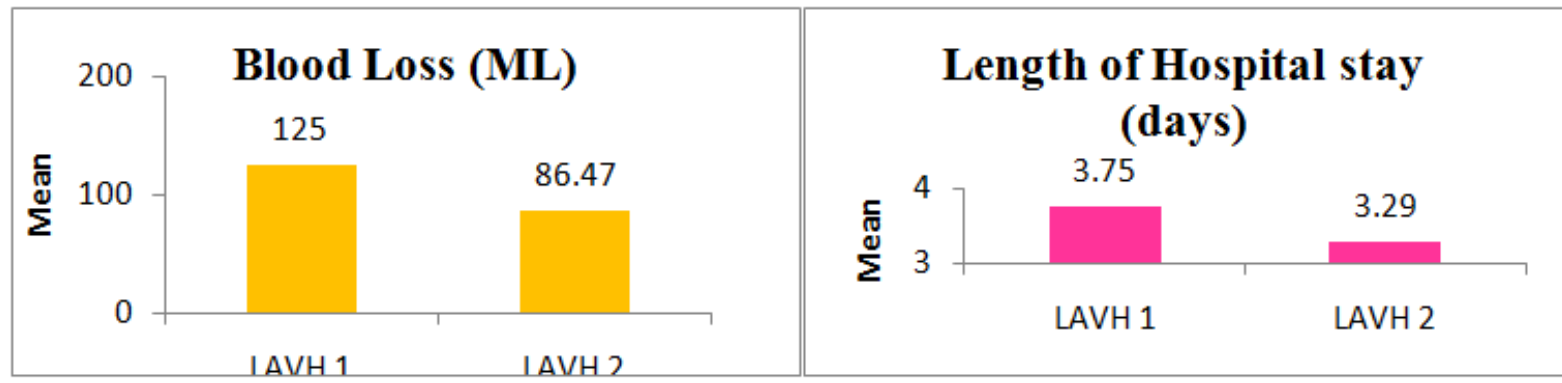

** Highly significant (Significant at $1 \%$ ); *Significant at $5 \%$

\section{Discussion}

1. Difficulties of Surgeon: Initially when the laparoscopic surgery was started the duration of surgery was prolonged. The total duration of surgery was about 150 to 180 minutes. The main difficultly was in reflecting the utero vesical fold of peritoneum and pushing the bladder down and cauterising the uterine arteries after skeletonising. Operating time for abnormal hysterectomy ranged from $40 \mathrm{~min}$ to $80 \mathrm{~min}$.

2. Out of 7 cases of LAVH which were converted to laparotomy two cases were due to bleeding while cauterizing the uterine arteries. The bleeding could not be arrested laparoscopically and hence converted to laparotomy.

3. In another 2 cases there were dense adhesions of tubes\& ovaries to posterior wall of uterus. We tried to release the adhesions but could not succeed. Fearing injury to intestines the surgery was converted to laparotomy. The adhesions were probably due to previous PID.1 case was due to endometritic adhesion and there were endometritic nodules in POD and small haemorrhagic cysts in ovaries

4. Another 2 cases of conversion to laparotomy was due to suspected bladder injury. There was bleeding from base of the bladder when pushing down. During laparotomy it was found to be injury to a small blood vessel andhaemostasis secured.

5. In another case it was an injury to rectal serosa while opening POD vaginally. Surgeon was called over and laparotomy done and serosal injury $(1 \mathrm{x} 1 \mathrm{~cm})$ sutured in 2 layers.

6. Blood loss during surgery was greater during abdominal hysterectomies because of the Pfannensteil incision when compared to LAVH cases. 35\% of Abdominal Hysterectomy Cases required intra OP or Post OP blood transfusion whereas only $10 \%$ of LAVH cases only required blood transfusion.

7. The mean length of stay was longer for abdominal hysterectomy than for LAVH patients. (6 days vs. 4 days respectively). Hospital costs were initially greater for LAVH cases because of increased operating time and costly instruments and the high complication rate in the initial period.

8. The postoperative pain was significantly low in LAVH cases compared to Abdominal Hysterectomy patients. (12\% Vs. 82\%) The LAVH Patients were ambulant early and returned to daily chores and normal diet early and required less assistance by the relatives postoperatively.

9. The proportion of abdominal hysterectomies during the study period at the centre fell considerably after introduction of LAVH in 2015. The proportion of unassisted vaginal hysterectomies did not change however.

10. Hospital costs were significantly greater for LAVH than abdominal hysterectomy and unassisted VH patients because of increased operating time and instruments also accounted for increased costs. LAVH patient suffered complications at the same rate as other groups.

11. In LAVH cases there was no incidence of wound infection. In 5 cases of abdominal hysterectomy there was post-operative wound infection. In one case woundwas restored under anaesthesia.

\section{Conclusion:}

The average length of stay is reduced in LAVH patients.

Post Op pain and blood loss during surgery is less.

Initially in a tertiary centre for a beginner the complication rate and costs higher but in the long run the cost effectiveness will be higher because of reduced hospital stay and reduced blood transfusions and antibiotic usage.

Regardless of the difficulties in the initial periodLAVH can reduce the number of patients requiring laparotomy for hysterectomy.

Laparoscopic surgeries can be extended to peripheral hospitals in future with proper training and infrastructure and patients are benefited. 


\section{References}

[1]. Int $\mathbf{J}$ Gynecol Cancer. 2010 May;20(4):570-5. doi: 10.1111/IGC.0b013e3181d8b105.Laparoscopically assisted vaginal hysterectomy (LAVH) versus total abdominal hysterectomy (TAH) in endometrial carcinoma: prospective cohort study.Devaja $\underline{\mathrm{O}}^{1}, \underline{\text { Samara I, Papadopoulos AJ. }}$.

[2]. Comparison of Laparoscopically Assisted Vaginal Hysterectomy and Abdominal Hysterectomy: A Randomized Controlled TrialKiattisak Kongwattanakul, MDKovit Khampitak, MDDepartment of Obstetrics and Gynecology, Faculty of Medicine, KhonKaen University, KhonKaen, Thailand DOI: http://dx.doi.org/10.1016/j.jmig.2011.10.003

[3]. Laparoscopic assisted vaginal hysterectomy (LAVH) - An effective alternative to conventional abdominal hysterectomyNisha Kapoor, Seema Manuja, Aruna Mittal, Meenakshi GuptaOriginal ArticleFirst Online: 23 June 2011 DOI: 10.1007/s13224-010-0071-7Kapoor, N., Manuja, S., Mittal, A. et al. J Obstet Gynecol India (2010) 60: 429. doi:10.1007/s 13224-010-0071-7Tips from Other Journals

[4]. Laparoscopic vs. Abdominal Hysterectomy: a Comparison Am Fam Physician. 2004 Oct 15;70(8):1570-1575.

[5]. Ulster Med J. 2006 Jan; 75(1): 54-58.Comparison of Laparoscopic-assisted Vaginal Hysterectomy, Total Abdominal Hysterectomy and Vaginal HysterectomyG McCracken, MB, BCh, BAO, MRCOG, Specialist RegistrarG McCracken, D Hunter, MD, Specialist RegistrarD Hunter, D Morgan, MB, BCh, BAO, Senior House OfficerD Morgan, JH Price, MD, FRCOG, FRCPI, Consultant GynaecologistJH Price,

\section{Other References}

[6]. Keshavarz H, Hillis SD, Kiele BA, Marchbanks PA. Hysterectomy Surveillance-United States, 1994-1999. MMWR CDC Surveillance Sum. 2002;51(SS05):1-8

[7]. The Royal College of Obstetrics and Gynaecology. The management of menorrhagia in secondary care. The Royal College of Obstetrics and Gynaecology; 2004. National Evidence-Based Clinical Guidelines. Available from: www.rcog.org.uk.

[8]. Clinch J. Length of hospital stay after vaginal hysterectomy. Br J Obstet Gynaecol.1994;101(3):253-4. [PubMed]

[9]. McPherson K, Metcalfe MA, Herbert A, Maresh M, Casbard A, Hargreaves J, et al. Severe complications of hysterectomy: the value study. Br J Obstet Gynaecol.2004;111(7):688-94. [PubMed]

[10]. Reich H, De Caprio J, McGlynn F. Laparoscopic hysterectomy. J Gynaecol Surg.1989;5:213-6.

[11]. Farquhar CM, Steiner CA. Hysterectomy rates in the United States 1990-1997. Obstet Gynecol. 2002;99(2):229-34. [PubMed]

[12]. Lumsden MA, Twaddle S, Hawthorn R, Traynor I, Gilmore D, Davis J, et al. A randomised comparison and economic evaluation of laparoscopic-assisted hysterectomy and abdominal hysterectomy. Br J ObstetGynaecol. 2000;107(11):1386-91. [PubMed]

[13]. Price JH, Nassief SA. Laparoscopic-assisted vaginal hysterectomy: initial experience. Ulster Med J. 1996;65(2):149-51. [PMC free article] [PubMed]

[14]. Garry R, Fountain J, Mason S, Hawe J, Napp V, Abbott J, et al. The eVALuate study: two parallel randomised trials, one comparing laparoscopic with abdominal hysterectomy, the other comparing laparoscopic with vaginal hysterectomy. BMJ. 2004;328(7432): 129-33.Epub 2004 Jan

[15]. Campbell ES, Xiao H, Smith MK. Types of hysterectomy: comparison of characteristics, hospital costs, utilization and outcomes. JReprod Med. 2003;48(12):943-9. [PubMed] 